\title{
Epilepside Gebelik, Doğum ve Doğum Sonu Sürecin Yönetimi ve Bakımı
}

\author{
Management and Care of Epilepsy During Pregnancy, Birth and Postpartum
}

\section{Sedef ASLAN ${ }^{1}$, Anayit M. COŞKUN ${ }^{2}$, Gizem ORAL ${ }^{1}$}

1. Bezmialem Vakıf Üniversitesi, Sağlık Bilimleri Fakültesi, Hemşirelik Bölümü 3. Sınıf Öğrencisi, İstanbul

2. Bezmialem Vakıf Üniversitesi, Sağlık Bilimleri Fakültesi, Hemşirelik Bölümü Öğretim Üyesi, İstanbul

\section{$\ddot{O Z Z E T}$}

Epilepsi, doğurgan çă̆l kadınların \% 0,5' inde etkili olup en sık görülen kronik nörolojik bir hastalıktır. Gebeliği komplike hale getirebilen bu durum, hem anne hem de fetüs ve yenidoğan açısından yaşamsal sorunlara neden olabilmektedir. Dolaylsiyla prekonsepsiyonel, gebelik, doğum ve lohusalık dönemlerinde epilepsi takibi ayrı bir önem taşımaktadır. Gebelik planlayan ve özellikle antiepileptik ilaç (AEI) kullanan epileptik kadınların, nöral tüp defekti riski nedeniyle gebelikten 2-3 ay önce yeterli doz folik asit kullanmaya başlamaları önerilmektedir. Anne ve fetusun sağlıklı bir gebelik süreci geçirilebilmeleri için, prenatal tarama ve tanı testlerinin yapılması, uygun monoterapi ilaç seçimi, nöbetlerin kontrol altına alınması ve rutin gebelik izlem ve bakımı ile ilgili eğitim ve danışmanlık verilmesi uygun olacaktır. Innatal dönemde de AEI rejiminin düzenli olarak sürdürülmesi gerekmektedir. Epileptik gebelerin vajinal doğum yapmasında bir sakınca yoktur. Ancak literatür bilgileri, sezaryen doğum tercih edildiği yönündedir. AEI kullanan epileptik anne bebeklerinde hemoraji riski nedeniyle $K$ vitamin desteği unutulmamalıdır. Çoğu AEİ'ler anne sütünden bebe ğe geçebildiği halde bebek için zararlı düzeyde ve emzirmeye kontrendike olmadiğ belirtilmektedir. Bu nedenle postnatal dönemde hemşirelerin emzirmeyi desteklemeleri ve anneye danışmanlik vermeleri önemlidir. Doğum sonrası nöbetlerin tetiklenmemesi için epileptik annelerin diğer lohusa popülasyonuna klyasla uyku ve dinlenmeye, beslenmeye ve dolaylsiyla destek sistemlerine daha fazla gereksinimleri vardır. Bu destek, yenidoğan bakımı konusunda da sürdürülmelidir. Epileptik kadınlar için postpartum hormonal kontraseptifler, AEI'lerle etkileşimi nedeniyle ilk tercih olmamalıdır. Bu makalede, epilepside prekonsepsiyonel bakımın önemi, gebelikte epilepsinin seyri, gebe, fetüs ve yenidoğan sağlı̆̆ına etkisi, doğum öncesi, anı ve sonrasi dönemde epilepsi yönetimine ilişkin bilgiler literatür ışı̆̆ı̆nda tartışılmıştır.

Anahtar Kelimeler: epilepsi, prekonsepsiyonel yaklaşım, gebelik, doğum eylemi, doğum sonu dönem, bakım ve yönetim

\section{SUMMARY}

Epilepsy is a common chronic neurological disorder that affects $0.5 \%$ of women in reproductive age. This health condition can cause pregnancy complications and vital problems in terms of mother, fetus and newborn. Therefore, the management of epilepsy is of special importance in preconceptional, pregnancy, birth and postpartum periods. It is suggested that epileptic women planning pregnancy, especially who are using antiepileptic drugs $(A E D$,$) should start to use adequate dose of folic acid 2-3$ months before pregnancy because of the risk of neural tube defects. In order to have a healthy pregnancy for both mother and fetus, using prenatal screening and diagnostic tests, appropriate monotherapy drug selection, control of seizures, education and counseling on routine pregnancy monitoring and care would be appropriate. The AED regime must be maintained regularly in the innatal period. There is no problem for the vaginal deliveries of epileptic pregnant women. However, literature suggests that cesarean birth is preferred. K vitamin supplements should not be forgotten due to the risk of hemorrhage in infants of epileptic mothers using AED. Although many AED's pass from mother to baby, it is stated that they are not harmful to the baby and there is no contraindication to breastfeeding. For this reason, nurses support and counseling for breastfeeding mothers is very important in the postnatal period. In order to avoid triggering postpartum seizures, epileptic mothers have a greater need for sleeping, resting, nutrition, and support systems compared to other postpartum populations. This support should also be maintained in relation to neonatal care. Postpartum hormonal contraceptives for epileptic women should not be the first choice because of the interaction with AEDs. In this article, the importance of preconceptional care in epilepsy, prognosis of epilepsy during pregnancy, its effects on pregnancy, fetus and neonatal health, management of epilepsy in prenatal, innatal and postnatal periods are discussed in the light of literature.

Keywords: epilepsy, preconceptional approach, pregnan$c y$, birth, postpartum period, care and management

\section{İetişim}

Sorumlu Yazar: Anayit Margirit Coşkun (Prof. Dr.)

Adres: Merkez Mahallesi Silahtarağa Caddesi No: 189 (İgdaş Gn. Müdürlüğü Karşısı) Eyüp, İstanbul Tel: +90 (536) 7746704

E-Posta: ancoskun@bezmialem.edu.tr

Makale Geliş: 10.05.2017

Makale Kabul: 19.08.2017

DOI: http://dx.doi.org/10.16948/zktipb.311738 


\section{GíRiș}

Epilepsi, kortikal nöronlardaki anormal ve aşırı elektriksel deşarj sonucu ortaya çıkan ani, tekrarlayıc1, tanımlanabilen bir olayla tetiklenmemiş epilepsi nöbetleri ile karakterize bir hastalıktır [1]. İnsanoğlu tarafından en eski bilinen ve halen en s1k görülen nörolojik hastalıklardan biridir. Tüm yaş, sosyal sınıf ve ülkelerde görülmektedir. Dünyada epilepsi prevalansının, yaklaş1k \% 1 olduğu ve 65 milyon insanın hastalıktan etkilendiği tahmin edilmektedir. $\mathrm{Bu}$ kişilerin \%80'I gelişmekte olan ülkelerdedir. Dünya Sağlık Örgütünün prevalans çalışmalarında, gelişmiş ülkeler için ortalama epilepsi prevalans1 $6 / 1000$ ve gelișmekte olan ülkelerde bu oran ortalama 18.5/1000 olduğu bildirilmektedir. Düşük sosyo ekonomik düzey ve sağlik hizmetlerinden sinırlı yararlanma, epilepsi insidans ve prevalansını artırdığı belirtilmektedir. Epilepsi tanısı almış olanların sıklığı ülkemizde, binde 7'dir. Hastalık yaş artıkça bir miktar azalma göstermekle birlikte cinsiyet açısından farklıl1k göstermemektedir [2-4]. T1bbi ve cerrahi tedavi ile bu hastaların \% 80'i nöbetlerden çok az etkilenerek veya hiç etkilenmeyerek günlük yaşantısını sürdürebilmektedir.

Diğer kronik hastalıklar gibi epilepsi de tamamen iyileşmez. Uzun süreli tedavi ve izlem gerektiren bir hastalık olup bireyin yaşam kalitesini önemli ölçüde etkiler. Epilepsi tedavisinde ilk basamak tanının doğru konması ve ilaçla tedaviye gerek olup olmadığının belirlenmesidir. Hastalığın tanı ve tedavisindeki güncel gelişmeler ve bunun sonucu yaşamdaki iyileşmeler epileptik kadınların sağlıklı çocuk sahibi olmalarına imkan vermiştir. Epileptik gebeler, büyük oranda sağlıklı çocuk doğurmaktadırlar. Ancak prematür doğum, fetal gelişme geriliği, düşük doğum ağırlı̆̆1, konjenital malformasyon, fetal ve neonetal ölüm risk oranları, özellikle AEİ kullanan epileptik gebelerde normal popülasyona göre artı̧̧ göstermektedir [5-7].

$\mathrm{Bu}$ makalede, epileptik kadınların prekonsepsiyonel döneme ilişkin bakımı, gebelik, doğum ve sonrası anne ve yenidoğan sağlığını riske atan durumlar ve yönetimine ilişkin konular irdelenmiştir.

\section{Prekonsepsiyonel Bakım ve Epileptik Kadı- na Yaklaşım}

Gebelik, kadın hayatını biyo-psikososyal yönden etkileyentıbbibakımvedestekgerektiren özel bir süreçtir. Bu süreç, gebelik öncesi dönem ile başlamaktadır. Gelişmiş ülkeler dahil dünyada pek çok gebelik, plansız olmaktadır. Oysa gebelik öncesi kadın ve eşinin sağlık durumu ve sağlık alışkanlıkları doğacak olan bebeğin kaderini belirlemektedir. Prekonsepsiyonel bakım kavramı, gelişmiş ülkelerde yaklaşık otuz yıl önce kötü obstetrik sonuçları önlemek amaciyla gündeme gelmiştir. Konsepsiyon öncesi dönemde anne ve baba adayının sağlığını geliştirmeyi öngören prekonsepsiyonel bakım yaklaşımı, sağlıklı gebeliğe ve sağl1klı bebeğe ulaşmak için gebelik öncesi birtakım girişimleri kapsar. Anne ve fetus için risk oluşturan fiziksel, tıbbi ve psikososyal durumları gebelikten önce saptayarak uygun şekilde çözmek veya yönlendirmek esasina dayanan bir koruyucu hizmettir [8]. Bu kapsamda doğurganlik dönemindeki tüm kadınlar, eşleriyle birlikte mevcut ya da olas1, kronik, genetik ya da ailevi hastalık, teratojenik etkenlere maruziyet durumları değerlendirilmeli ve gerekli önlemler alındıktan sonra çiftin gebeliği planlanmaktadır. Ayrıca gebe ve fetusun sağlığını korumak amacıyla folik asit proflaksisi, bağışıklama, sigara-alkol kullanımının bırakılması, obesitenin düzeltilmesi, dengeli beslenme vb. sağlıklı yaşam davranışları gibi koruyucu önlemler de alınmaktadır. Folik asit yetersizliği olan gebelerin bebeklerinde, düşük doğum ağırlığg, prematür doğum ve en önemlisi nöral tüp defekti gibi ciddi risklerin görülme sıklığı artmaktadır $[8,9]$. Tüm bu nedenlerle "prekonsepsiyonel danışmanlık", çocuk sahibi olmak isteyen epilepsili kadının izleminde en önemli aşamayı oluşturmaktadır.

Folik asit, santral sinir sistemi gelişiminde öncelikle gerekli bir vitamin desteğidir. Bu önem, özellikle hızlı hücre bölünmesinin olduğu embriyonel dönem ve gebeliğin ilk trimesteri için daha da artmaktadır. Gebe kalmayı planlayan epileptik kadınların gebe kalmadan 2-3 ay önce $0.4-0.5 \mathrm{mg} / \mathrm{gün}$ folik asit kullanmaya başlamaları ve gebeliğin 3 . ile 8 . haftalarında da devam etmeleri öngörülmektedir. Folik asit, nöral tüp defekti oluşumunu \%75-80 oranında azalttığ ve 1-a düzey kanıt temelli bir uygulama olduğu bildirilmektedir [1, 7, 8, 10-13]. Gebelik öncesi başlayarak gebelikte devam eden folik asit desteğinin, intrauterin dönemde antiepileptik ilaca maruz kalan çocukları kognitif bozulmaya karşı da koruduğu düşünülmektedir. Özellikle antiepileptik ajanlardan valproik asit ve karbazepin kullanan ve nöral tüp defekti görülme riski yüksek olan gebelere 4-5 mg/ gün dozunda folik asit takviyesi önerilmektedir [12-16]. Epilepsi hastalarında, yukarda belirtilen genel önlemler dışında gebelik öncesinde, antiepileptik ilaçların (AEI) terotenojenik potansiyelleri, ilaç kesimi ya da doz azaltma olasılığ $1 \mathrm{vb}$. durumlar nörolog ve kadın-doğum uzmanı birlikte konsültasyon yapıp hasta hakkında ortak bir karara varmalidır. 
Antiepileptik ilaç doz düzenlemeleri, gebe kalmadan önce yapılmalı ve gebelik sonrası ilaç miktarı ve sayısı ile oynanmamasına özen gösterilmelidir $[12,14,15]$.

Prekonsersiyonel danışmanlık yapılabilmesi için gebeliklerin planlı olması gerekmektedir. Dolayısıyla epileptik bir kadının gebeliği mutlaka planlı olmalı ve gebe kalmadan önce nöroloğu ile görüşmeli ve onayını almalıdır. Danışmanlık programlarıyla epileptik kadın ve çiftin, soruları yanıtlanarak olası kaygı ve endișeleri giderilir ve gebelik sürecini daha doğru yönetmeleri sağlanır. Epileptik gebeye, folik asit kullanımının önemi, gebelik sırasında nöbet sıkl1ğında değişim olabileceği, ilaç kullanımının ve AEİ düzeylerinin düzenli takibinin gerekli olduğu, hastalığın kalıtsal yönü, son ayda $\mathrm{K}$ vitaminin kullanılmasının gerekliliği, emzirmenin yararı ve olası sorunlar hakkında danışmanlık verilmelidir. Olası gebelikte antiepileptik ilaç dozlarının düzenleneceği, mümkün derece tek ilaç ve en az miktardaki doza indirileceği söylenir $[6,7,10,14,12,15]$.

\section{Antenatal Dönemin Epileptik Gebe ve Fetüs Açısından Riskleri ve Yönetimi}

\section{Nöbet Kontrolünün Önemi}

Gebelikte epileptik hastaların 1/3'de nöbet sıklığında artış meydana geldiği bildirilmektedir [5, 6, 10-12, 14]. Bu artışın, nöbetin tipi, epilepsi süresine bağlı olmadığı ifade edilmektedir. Bununla birlikte bir başka kaynakta özellikle fokal (parsiyel) epilepsisi olan veya çoklu antiepileptik ilaç tedavisi uygulanan gebelerde nöbet geçirme riskinin oldukça yüksek olduğu bildirilmektedir $[12,17]$. Ancak epileptik gebelerin yaklaşık yarısının bu dönemde nöbet geçirmedikleri de görülmüştür. Nöbetlerdeki artışın \%50'sinin gebeliğin 8.-16. haftalar arasinda \%35'inin ise 16.-24. haftaları arasinda olduğu belirtilmektedir [6]. Gebelik sırasında nöbet artışını açıklayan çeşitli hipotezler vardir. Bunlardan biri, hastalar aynı dozda, hatta bazen daha yüksek doz ilaç almalarına rağmen gebelikte fizyolojik olarak oluşan kan volüm (plazma ve şekilli elementler) artışının, alınan ilacın kandaki düzeyini azaltacağı yönündeki açıklamadır. Ancak plazma ilaç konsantrasyonundaki azalma, her zaman nöbet artıșı ile beraber seyretmeyebilmektedir. Bununla birlikte nöbetleri artan hastaların plazma ilaç düzeyleri, genellikle tedavi dozun altında bulunduğu görülmüştür. Nöbet riski perinatal dönemde en yüksek olduğu bildirilmektedir. Pospartum döneminde ise bunun tam tersi olmakta, doğumda ve lohusalikta kan ve sivi kayb1 sonucu plazma volümündeki azalma, alınan antiepileptik ilaç dozunun kandaki düzeyini artırmaktadır. Dolayısıyla gebeliğin neden olduğu ilaç düzeyindeki değişiklik postpartum dönemde hızla eski haline döneceği için lohusaya aşırı dozdan korumak amacı ile serum düzeyi takibi ve yakın klinik gözlem önerilmektedir [2, 6, 11, 12, 18]. Gebelikte geçirilen tek bir nöbet atağının fetüse olumsuz etki yarattı̆̆ına yönelik kesin bir kanıt yoktur. Bununla birlikte, nöbet sırasında düşme ile ilişkili olarak yaşanan karın travması, komplikasyonlara neden olabilmektedir [12, 14, 19]. Antiepileptik ilaçların farmakodinamik ve farmakokinetik etkileri de gebelerde değişmektedir. Burada en önemli sorun, AEI' nin teratojenik etkilerinin olmasıdır. Ancak unutulmaması gereken bir konu gebelikte kontrol edilmeyen konvülsif nöbetlerin, AEİ tedavisinden daha fazla teratojenik potansiyele sahip olmasidır. Epilepsi krizi hem annenin hem de fetusun hayatını tehlikeye sokan önemli bir sorundur. Gebelikte geçirilen epileptik nöbetlerin (tonik ve klonik) erken doğum sıklığında ve düşük doğum ağırlıklı bebek görülme oranında art1şa neden olabildiği gibi fetal hipoksi, fetal intrakranial kanama ve fetal kayıplara yol açtı̆̆ bildirilmektedir. Gebelikte epileptik nöbetin uteroplesantal hipoksiye yol açtığı, bunun da fetal hipoksi, kalp atımlarında yavaşlama, periventriküler hemoraji, fetal ölüm veya erken doğuma neden olabildiği rapor edilmiştir. $\mathrm{Bu}$ olumsuz tablonun gebelikte geçirilen nöbet sıklığ 1 ve süresiyle de ilgili olduğu belirtilmektedir [19]. Fetusun prenatal dönemde kriz sonrası maruz kaldığ 1 hipoksiye bağlı iskemik beyin hasarı, yüksek oranda morbitide ve mortalite görülebilmektedir. Ayrıca prenatal ve perinatal iskeminin beyin maturasyonunu ciddi oranda etkilediği ve bunun da ilerde önemli nörolojik hastalıklara yol açtığı bilinmektedir. Gebeliğin ilk üç ayında nöbet geçiren annelerin bebeklerinde kongenital malformasyon oranının daha yüksek olduğu bildirilmektedir $[6,10-12,20]$.

\section{Gebelik ve Antiepileptikler}

Antiepileptik tedavinin fetüse getirebileceği riskler ile gebelik sırasında oluşan epileptik nöbetlerin anne ve bebek sağlığına etkisi dikkatle değerlendirilmelidir. Özellikle AEİ kullanan epileptik gebelerde, genel popülasyona kıyasla preeklampsi, non-proteinürik hipertansiyon, son trimaster kanamaları, abortus, prematür doğum (çoğu kez 34. haftadan önce), IUGR, majör malformasyon, atoni kanamasi vb. komplikasyonlar ve sezaryen dahil müdahaleli doğum oranlarının normal popülasyona göre 2-3 kat artığı bildirilmektedir [12, 19]. Borthen ve arkadaşlarının 2010 yılında yayımladıkları toplum temelli kohort çalışmada, 2805 epileptik gebe ile 362.302 epilepsi öyküsü 
olmayan gebe, gebelik, doğum ve yenidoğan riskleri açısından değerlendirilmiştir. Çalışmada epileptik gebelerin \%33.6'sinın gebeliklerinde AEI kullandıkları bildirilmiştir. Genel popülasyona göre epileptik gebelerde doğum eyleminde indüksiyon uygulama (OR, 1.3; \%95 CI, 1.3-1.6), sezaryen olma (OR, 1.4; \%95 CI, 1.3-1.6) ve postpartum kanama (OR, 1.2; \%95 CI, 1.1-1.4) oranları hafif düzeyde de olsa artıș gösterdiği ve AEİ kullanan gebelerde bu artışın daha belirgin olduğu belirtilmiştir. Miad geçmesi, preeklampsi ve geç dönem gebelik kanamaları açısından epileptik olan ve olmayan gebeler arasında fark bulunmamıştır [21]. Veiby ve arkadaşları tarafindan 2009 yılında Norveç’te geniş bir örneklem grubuyla yürütülen bir başka benzer çalışmada da epileptik olmayan, olan ancak AEİ kullanmayan ve AEİ kullanan üç farklı gebe grubundaki risk faktörler belirlenmeye çalıș1lmıștır. Örneklem grubunda AEİ kullanan epileptik gebe oran1, \%34 tür. Bu son grupta diğerlerinden düşük kilolu ve prematür bebek, baş çevresinin $<2.5$ persantilin altında ve düşük Apgar puanlı bebek oranlarının anlamlı düzeyde yüksek olduğu belirlenmiştir.

Majör konjenital malformasyon oranı normal popülasyona kıyasla az bir yükseklik saptanmıştır [22]. Oysa bir başka veride epilepsili gebelerin bebeklerinde konjenital malformasyon görülme sıklığı, genel popülasyonla kıyasla 2-3 kat artış gösterdiği belirtilmiştir. AEİ kullanan epileptik gebelerde en yaygın tanımlanmış majör anomaliler, kojenital kalp hastalığı, nöral tüp defekti, urogenital defekt (glandüler hypospadias), dudak ve/veya damak yarığ1, ekstremite anomalileri, genitoüriner malformasyonlardır. $\mathrm{Bu}$ riskin, özellikle embriyonel dönem ve ilk trimesterde antiepileptik ilaca maruz kalanlarda görüldügü belirtilmektedir. Bu defektler açısından genel popülasyonda risk, \%2-3 iken bu grupta \% 1.25- arasında değiştiği rapor edilmektedir [6]. AEİ ların tüm bu zararlı etkilerine karşın konvülzif nöbetlerin anne ve bebek sağlığına olan zararlı etkileri çok daha büyüktür. Sonuç olarak, hem AEİ tedavisi hem de epileptik nöbetler, fetüsü olumsuz etkileyebilmektedir. Tek ilaç kullanımı ile bu riskler, \%6-7 iken iki veya daha fazla AEİ kullanımında \%10-15'e yükselebilmektedir. Anne kanında ilaç düzeyindeki artışın ve kombine AEİ kullanımının konjenital malformasyon riskini artırdı ğ 1 bilinmektedir. Valproat, Karbamazepin ve Fenitoin kombinasyonu kullanan kadınlarda risk oranı \%50'ye kadar yükselebilmektedir. Değişik antiepilektik ilaçlarla yapılan değerlendirmede, monoterapide en yüksek konjenital malformasyon gelişme riski, valpronik asit, fenobarbital kullanımında iken en düşük risk de lamotrijin ve levetirasetam kullanımında bulunmuştur.
Yüksek doz valporik asit, fetal malformasyon riski artırmaktadır. Valporik asit nörol tüp defektleri, hipospadias, kardiyak anomaliler, yarik damak-dudağa daha sik sebep olmaktadır $[1,12,14,17,20,23]$. Gebenin antiepileptik rejimi, doğum sırasında da devam ettirilmelidir.

Eylemde bulant1, kusma ya da anestezi nedeniyle rejime uyulması mümkün olamadığında başlangıç dozu $10 \mathrm{mg} / \mathrm{kg}$ olmak üzere IV uygulanan fenitoin rejiminin, 2 saat sonra ikinci dozu $5 \mathrm{mg} / \mathrm{kg}$ olarak uygulanması önerilmektedir. Yüksek riskli ilaç kullanan epileptik kadınlar, plansız gebelik yaşamış ve bu kullanım dozu organogenez döneminde de devam etmiş ise fetüste nöro-gelişimsel gerilik görülebilir Tüm bu sorunlar nedeniyle gebelikte nöbet kontrolünün sağlanması için ilaç düzeyi izlenmeli ve gereğinde doz titrasyonuna gidilmelidir $[12,15,20]$. Doğal olarak bu risklerin en fazla organogenez ve ilk trimasterde oluştuğu ifade edilmektedir Ayrıca gebelikte enzim indükleyen (tetikleyen) AEI'leri kullananlarda yenidoğanın kanama olasılığ 1 artıracağından tüm gebeler 36. haftadan miada kadar K vit $20 \mathrm{mg} / \mathrm{günde}$ kullanması önerilmektedir [19]. AEİ kullanımının, çocuk zekasını nasıl etkilediği aile için merak konusu olmaktadır. Oysa ilacın doğrudan etkisi, çok az olmaktadır. Bu konuda esas olan anne ve babanın genetik predispozisyonu, annenin gebelikte geçirdiği nöbetlerin sıklığı, epilepsi tipi, kalıtsal beyin hastalığının varlığıdır [6]. En tehlikeli kombinasyonun valporik asit ve lamotirijin olduğu belirtilmektedir [1].

Epileptik kadın gebe kaldıktan sonra, nöbetleri monoterapi ile kontrol altındaysa AEİ'nin kesinlikle değiștirilmemesi önerilmektedir. Teratojenik yan etkileri azaltmak amaciyla AEI değişiminin kontrendike olduğu ve ilaç değişisimiyle nöbetlerin kontrolden çıkabileceği, bunu yönetmek üzere iki çeşit AEİ'ye ihtiyaç olabileceği ve sonunda teratojenite riskinin daha da artabileceği belirtilmektedir. Ĕger, hasta politerapi sırasında gebe kalmış ve nöbetleri de kontrol altında ise monoterapiye geçiş denenebilir. Ancak, bir ilacın dozunun azaltılması nöbetin tekrarına yol açabileceğinden, hasta mutlaka yakından izlenmelidir. Planlı bir gebelikte, tedavi ile ilgili her değişiklik mutlaka en az altı ay önce yapılmalıdır [6].

\section{Gebelik Döneminde Bakım}

Epileptik gebelerde antenatal bakımın amacı, nöbetlerin en iyi biçimde kontrol altına alınmasıdır. Epilepsili kadınlar riskli gebelik grubunda yer aldıklarından komplikasyonlar1 önlemek amacıyla nörolog ve kadın-doğum uzmanı tarafindan birlikte takip edilmelidir [6]. 
Fetal anomali ve konjenital malformasyon aç1sından epileptik anne adayların gebelik dönemindeki rutin kontrolleri ve tarama/tanı testleri, antenatal bakımın önemli bir aşamasını oluşturur ve özenle yapılmalıdır.

Çift, prenatal tanı ve tarama testleri açısından bilgilendirilmelidir. Organogenezis, 10. gebelik haftasına kadar oluşur. İdeal tarama testleri, basit, güvenilir, hızlı sonuç veren ve ekonomik olandır. Yüksek özgünlük ve duyarlılığa sahip olmalıdır. Prenatal değerlendirmede üç temel işlemden söz etmek mümkündür. İlki serum markırları, sonraki ultrasonografi ve sonuncusu ise amniyotik sıvı analizidir. AEİ kullanan epileptik gebelerde, "nöral tüp defekt" riski açısından 16. gebelik haftasinda serum alfafetoprotein düzeyine bakılması, yine fetüsteki yapısal anomali açısından 18-22. haftalarda II. Düzey ultrason değerlendirmesi önerilmektedir. Günümüzde ultrasonografi alanında gelişen teknolojinin yansıması görülmekte ve gebeliğin 12 . haftasından itibaren malformasyonlar, hata pay1 düşük olarak saptanabilmektedir. Kadın-doğum uzman1, erken gebelik ultrasonografisini, transvajinal prob ile 8 . gebelik haftasından önce gebelik tanıs1 ve gebelik ürününün intrauterin konumu hakkında bilgi almak üzere gerçekleştirir. Yine ayrıntılı ultrason değerlendirmesinde, fetal ekokardiografi ve fetal yüzün görüntülenmesi de önemlidir.

İlerleyen gebelik haftalarında ise ultrasonografide fetusun IUGR açısından değerlendirmesi önem taşımaktadır. Yine gerektiğinde kordon villus biyopsisi ve amniyosentez de tanı olarak kullanılabilir [14, 17]. Tarama ve tanı testleri dıșında gebe ve ailesi gebelik süreci ve doğuma hazırlık açısından eğitilmeli ve ilaç kullanımı, beslenme, kişisel hijyen, bağışıklama, ağız ve diş sağlığı, uyku ve dinlenme, cinsel yaşam, egzersiz gibi konularında danışmanlık verilmelidir.

\section{İnnatal Döneminde Epilepsi Yönetimi}

Epileptik gebeliklerde intrapartum dönem de çok önemlidir. Çünkü konvülsiyonlar ortaya çıkabilir, böylece maternal ve fetal morbidite ve mortalitede artış gözlenebilir. Epileptik gebelerin vajinal doğum yapmasında bir sakınca yoktur. Doğum eyleminde de annenin gebelik döneminde kullandığ 1 AEİ rejimini düzenli olarak sürdürmesi gerekmektedir. Bulantı-kusma ya da anestetikler nedeniyle AEİ rejimi uygulanamadığında tedavi, IV olarak devam ettirilebilir. Nöbet riski, doğum sırasında ve takip eden 24 saat içinde \%1-2 oranındadır. Doğum sırasında annenin oksijen gereksinimi artığ 1 için geçirilecek nöbet, diğer dönemlere göre fetuste daha fazla hipoksi yaratır. Bu nedenle epileptik gebe, doğumunu maternal ve neonatal resustasyon olanağına sahip tam teşekküllü bir hastanede yapmalıdır. Ayrıca doğum yapılacak merkezlerin annenin nöbetlerini tedavi edebilecek alt yapıya sahip olması da önem taşımaktadır. Miada doğru gebenin sıklikla tonik klonik veya uzamış kompleks kısmi nöbetleri oluyorsa elektif sezaryen de düşünülmelidir. Doğum sırasında aşırı nefes alma, doğumu başlatan ve sürdüren hormonlar etkisiyle uyku debrivasyonu, ağr1 ve emosyonel stres nöbet riskini art1rabileceği için bu etkileri azaltmak amacı ile erken dönemde epidural anestezi tercih edilebilir. Doğum eylemi sırasında gebenin epileptik nöbet geçirme riski yüksek olmasa da büyük çoğunlukla doğum süresince düzenli AEİ kullanımının kesintiye uğraması, uykusuzluk, açlık ve ağrı gibi faktörler, göreceli olarak risk artış1na neden olabilir. Doğum sırasında nöbet olursa k1sa etkili benzodiazepinler veya fenitoin kullan1labilir. Ancak benzodiazepinler bebekte ciddi sedasyon, apne, hipotoni yapılabileceği unutulmamalıdır. Bu süreçte elektronik fetal monitör ile sık aralıklarla fetal kalp frekansı izlenmelidir. Doğumun ekspulsiyon dönemini kısaltmak ve hizlandirmak amaciyla forseps veya vakum kullanımı önerilmektedir. Bazen de sezaryen gerekebilmektedir. Epileptik gebelerde müdahaleli doğum oranı, diğerler populasyona k1yasla daha yüksek olduğu bildirilmektedir $[2,6$, $12,14,17,24]$. Doğum travayı sırasında yaşanabilecek bulantı, kusma, sıv1 kayb1, akut ağrı, bitkinlik, tükenmişlik vb. fiziksel ve psikolojik sıkıntılar, doğumun yönetiminde gelişebilecek komplikasyonların belirsizliği, epileptik gebelerde indüklenmiş doğum ve sezaryen oranını artırmaktadır. Bu konuda hekim de risk almak istemeyebilir. Bazen de epileptik gebeliklerde fetal anomali, erken doğum, preeklampsi, IUGR gibi eşlik eden artmış obstetrik komplikasyonlar, serazyen doğumu kaçınılmaz kılmaktadır. İnnatal dönemde anne ve fetusun yakından izlenmeli ve değerlendirilmelidir. Gebeye rutin innatal dönem bakımı ve konforu sağlanmalı ve ağr1 yönetiminde nonfarmakolojik yöntemle tercih edilmelidir. Doğum sırasında yenidoğan uzmanının da bulunması, bebeğe gerek görülen ilk girişimlerin hemen yapılması açısından gereklidir. Epileptik gebelerin çoğu için vajinal doğum tercih edilebilir. Doğum travayında uterin kontraksiyonlar, annenin enerji ve sivi kaybı, tonik klonik nöbetleri tetikleyebilir. Epileptik gebe açısından \%1-2 olarak bu olasilık nedeniyle epileptik gebe travay sirasinda asla yalnız bırakılmamalıdır. Yine bu süreç, IV diazepam ya da lorazepam verilerek yönetilebilir. Şayet gebeliğin son döneminde tonik klonik kasılmalar sıklaşır ve nöbetler uzun süreli olursa elektif sezaryen seçilmelidir. Epileptik gebelerde de epidural analjesi önerilmektedir [14, 22]. 


\section{Postnatal Döneminde Epilepsi Yönetimi ve Emzirme}

Özellikle AEİ kullanan epileptik gebelere, doğum sonu dönemde hem lohusa hem de yeni doğanda oluşabilecek riskler nedeniyle daha yakın takip ve kapsamlı bakım verilmesi gerekmektedir. Borthen ve arkadaşlarının 2010 y1lı çalışmasında postpartum kanama durumu, epileptik vajinal doğum yapan gebelerde $\% 11.1$ olarak saptanırken epileptik olmayanlarda \% 9.4 olarak bulgulanmıștır. Müdahaleli vajinal doğumlarda bu oranın daha yüksek olduğu, buna karşın sezaryen doğum sonrası riskin referans grubuna benzer olduğu belirtilmiştir. $\mathrm{Bu}$ çalışmada epileptik gebelerde vajinal müdahaleli doğum sonrası atoni kanama olasılığının daha yüksek olduğu bildirilmiştir [21]. AEİ kullanan annenin bebeğinde yeni doğan hemorajik hastalıkların görülme riski artmıştır. Bu nedenle tüm yeni doğan bebekler için doğar doğmaz kas içine uygulanan $\mathrm{K}$ vitamin (1 mg) desteği, bu bebekler için de öncelikli yapılmalıdır [14].

Emzirme, tüm lohusa ve yeni doğanlar için yaşamsal önemini epileptik ve AEI kullanan anneler için de korumaktadır. Bu nedenle vajinal ya da sezaryen doğum yapan anneler, emzirme danışmanlığı ile desteklenmeli ve cesaretlendirilmelidir.

Özellikle sezaryen doğumlarda anne ve bebeğin bir süre de olsa birbirlerinden uzak kalmas1, emzirme sürecini geciktirse de servise alınan lohusaya hemen bebeği verilerek emzirme süreci başlatılmalıdır. Emzirme, epileptik anne ve yeni doğanlar için ayrı bir önem taşımaktadır ve anneler bu konuda cesaretlendirilmelidir. Cünkü epileptik anneler, sütüne AEİ geçip bebeğine zarar verebileceği yönündeki kaygısı nedeniyle emzirmeye temkinli yaklaşabilmektedirler. Bebeğe anti epileptik ilaçların etkisi, önemli ölçüde anne sütünde AEİ düzeyi, yenidoğanda AEI metabolizması ve ilacin eliminasyon yarılanma süresiyle ilgilidir. Anne sütünden AEİ atılımı, maternal serum proteine bağlanma derecesine bağlı olarak değişmektedir.

Phenytoin, carbamazepine ve valproate gibi AEİ lar, tüm yüksek derecede protein bağlanmalarda olduğu gibi, anne sütünde düşük konsantrasyonda bulunur. Buna karşın phenobabital ve primidone, daha düşük protein bağlanma durumunda olanlar gibi anne sütünde yüksek düzeydedir. Elde edilen veriler, lamotrigine ve topiramate gibi AEI'lerin anne sütünde önemli düzeyde bulunabileceğini, fakat yan etkilerinin olmadığını göstermektedir. Buna bağlı olarak çoğu antikonvülsan ilaçların, anne sütüne geçtiği halde bebek için zararlı düzeyde ve emziremeye kontrendike olmadı̆̆ını söylemek mümkündür $[6,14,19]$. Ancak sedatif antikonvülsanların bebekte hafif de olsa sedasyona neden olduğu bilinmektedir. Sonuçta AEI'ların çoğu, anne sütünden bebeğe geçebildiği halde miktarı, plasental geçiş kadar yüksek değildir ve sorun oluşturmaz. Bu nedenle epileptik annelerin bebeklerini emzirmeleri sakıncalı değildir ve desteklenmelidir. Bu arada lohusalık döneminde annenin yaşam biçimi ve rutinlerinin bozulması, yine gece sik sık uyanıp bebeği ile ilgilenmek zorunda kalmasi, yorgunluk ve bitkinliği nöbetleri tetikleyebilir. Bu konuda anne ve aile üyeleri dikkatli olmalı, anneyi destekleyerek dinlenmesine firsat vermelidir.

Epilepsinin ailevi yatkınlığının olduğunu gösteren kuvvetli ipuçları mevcuttur. Epileptik sendromların temelinde, kromozomal bozukluklar, tek gen defektleri ve büyük çoğunlukla da kompleks kalıtım gibi farklı genetik geçiş şekilleri yatmaktadır. Epileptik sendromların yaklaşı \% 1 'i, Mendel tipi kalıtım özelliği gösteren tek gen mutasyonuna bağlı otosomal geçiş ile olur. Daha yüksek düzeyde epilepsi, kompleks bir kalıtıma bağlı olarak gelişir. Kompleks katılım, bir ya da daha fazla gen ile çevresel faktörlerin etkileşimi sonucu gelişen kalıtım modelidir.

Bireylerin yarısından fazlasında görülen idyopatik epilepsiler, kompleks genetik geçişe örneği oluşturabilmektedir. Bununla beraber kafa travmasi, ensefalit ve beyin tümörü vb. nedenlerden dolayı oluşan semptomatik epilepsilerde ailesel bir geçiş söz konusu değildir [3, 25].

\section{Doğum Sonrası Nöbetleri}

Uyku yoksunluğu, yorgunluk, tükenmişlik, kan ve sıvı kaybının doğum sonrası nöbet riskini artırdığı bilinmektedir. Ancak yeterli uyku ve dinlenme bu olasılığı önemli ölçüde azaltmaktadir.

Doğum sonrası annenin, destek sistemler kullanılarak, uyku ve dinlenmesinin sağlanması önemlidir. Aile üyeleri de bu konuda bilinçlendirilmeli ve evdeki desteğin sürdürülmesi sağlanmalıdır. Bebeğin güvenliğinin sağlanması adına annenin yalnız birakılmaması ve epilepi nöbeti sırasında bebeğin yaralanmaması için önlemlerin alınması gerekmektedir. Lohusa, kaza riskini nasıl azaltabileceği konusunda bilgilendirilmelidir. Bu öneriler arasında; bebeğin anne tarafından kucaklanması, bebeğin beslenmesi ve bebek bezi ve giysilerin değiştirilmesi yere oturur pozisyonda yapılması ve bebeğin banyosunu tek başına yapmaması sayılabilir $[14,26]$. 
Epileptik Kadının Doğum Öncesi, Anı ve Sonrası İzlem ve Bakım Öncelikleri.

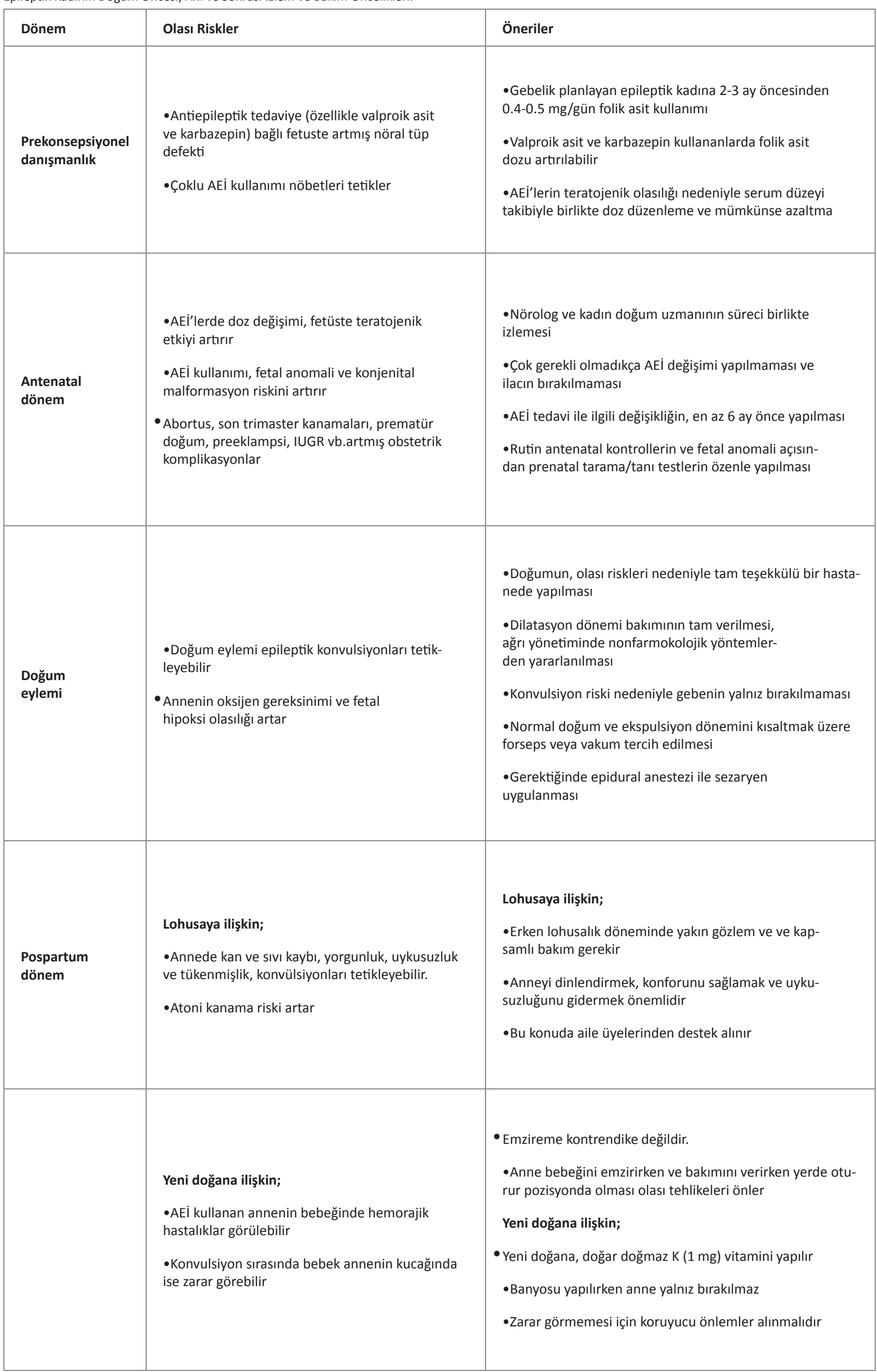




\section{Doğum Sonu Taburculuk Önerileri}

Kadın-Doğum uzmanı, anneyi taburcu etmeden önce yaklaşık 3-4 ay içinde nöroloğu ile iletişime geçmesini önermelidir. S1k aralıklarla gebelik ve doğum, anne ve yenidoğan sağlığ açısından risk oluşturur. Yukarda da belirtildiği gibi antiepileptik ilaç kullanan annelerin bebekleri, kullanmayanlara kıyasla daha fazla konjenital anomali riskine sahiptir. Gebelik boyunca kullanılan ve yüzde yüz güvenli bir antiepileptik ilaç mevcut değildir. Bu durum, ailenin bilmesi gereken önemli bir gerçektir. Doğum sonrası en sik gözlemlenen sorunlar, emzirme güçlügü, kontrasepsiyon ve izlem ile ilgilidir.

Öncelikle anne ve ailesinin aklından geçen soruların yanıtlanması ve emzirme danışmanlığı, yendoğanın anne sütünden yeterince yararlanabilmesi için önemlidir. Yine postpartum uygun kontrasepsiyon yöntem seçimi konusunda çifte danışmanlık verilmelidir. Hormonal kontraseptif yöntemlerin AEİ ile etkileşime girebileceği açıklanmalıdır. Epileptik kadınların kontrasepsiyon amaciyla non-hormonal yöntem kullan1mında hiçbir sakınca yoktur. Bariyer yöntemler, intrauterin araç (UID) öncelikli tercihler arasında yer almalıdır. AEİ kullanımı, sıklıkla hepatik enzim indükleyicidir ve hormonal kontraseptiflerden hem östrojen hem de progesteron metabolizmasını hizlandırır. Sadece progesteron içeren haplar, üç aylık iğneler (depo- provera) ve implantlar, epileptik kadınlar için ilk tercih olmamal, hatta önerilmemelidir. Çünkü AEI'ler, progesteron ile etkileşime girerek etkinliğini azaltırlar. $\mathrm{Bu}$ yöntemle korunmanın etkili olabilmesi için yüksek doz kullanılması, yani dozunun iki katı artırılması gerekir. İmplantların sabit doz salınımı nedeniyle epileptik kadınlar için hiç uygun olmaz. Kombine oral kontraseptiflerin (KOK) epileptik kadınlarda kullanımı ise yine doz artışı ile mümkün olabilmektedir. Çünkü AEİ 'ler, KOK'ların etki mekanizmasını azalttığı gibi ara kanamalara da neden olabilmektedir. Oral kontraseptif ve enzim indükleyici AEİ kullanan kadınların, ek olarak bariyer yöntem de kullanmaları önerilmektedir. AEI kullanan epileptik kadınlarda acil kontrasepsiyon gerektiğinde hormonal ilaçlar yerine intrauterin araç tercih edilmelidir [2, 14].

\section{Yenidoğan Bakımı}

Emzirme sirasında annenin fiziksel yorgunluk ya da uyku yoksunluğu nedeniyle nöbet geçirme riski artmış olabilir [18]. Nöbetlerin tipi, şiddeti ve sıklığına göre, en fazla jeneralize myoklonik epilepside olmak üzere, bebeğin yaralanma riski söz konusudur. Bunu önlemek için $[6,19]$;
- Annenin aşırı yorgunluktan kaçınması,

- Annenin kendisini iyi hissetmediği durumda bebeğini güvenli ve uygun bir alana (oyun parkı veya beşik, karyolaya gibi) bırakması,

- Emzirme sirasında bebeği kucağından düşürme riskine karşı önlem olarak anne, yerde minderlerle çevrili ve bir duvara yaslanmış şekilde çocuğunu emzirmesi,

- Bebeğinin giysileri ve alt bezini yer minderinde değiştirmesi,

- Bebeğin banyosunu baba ya da ev halkından destek alarak yapmas1,

- Bebek büyüdüğünde ve ek gidaya geçildiğinde beslenme işlemini, yerde oturarak yapmas1

- Bebeği taşırken yastıklı bir taşıyıcı veya askılı bir anne kucağı kullanması,

- Merdiven inip çıkarken bebeği aile üyeleri tarafından taşınması gerektiği güvenlik açısından önemle vurgulanmaktadır.

\section{KAYNAKLAR}

1. Kutlu G, Erdal A, Aydoğan S, B. Gomceli Y, E.İnan L. Gebelik Sirasinda Epilepsili Kadinların Takip ve Tedavisi. Journal of Neurological Sciences (Turkish) 2012; 29:(3):527-534.

2. Aykut Bingöl C.(Ed.) Epilepsi Rehberi Türk Epilepsi ile Savaş Derneği. Epilepsi Dergisi 2012; 18(1):26-38.

3. Görgülü Ü, Fesci H. Epilepsi ile Yaşam: Epilepsinin Psikososyal Etkileri. Göstepe Tip Dergisi 2011; 26 (1): 27 32.

4. Adadıŏ̆lu Ö, Ŏguz S. Epilepsi ve Öz Bakım. Epilepsi Dergisi 2016; 22 (1):1-4.

5. Akdă̆ G, İ. Algın D, O. Erdinç O. Epilepsi. Osmangazi Tıp Dergisi 2016; 38 (özel sayı 1): 35-41.

6. Atakl D. Gebelik ve Epilepsi. Epilepsi 2002;8(2): 113-119 http://www.journalagent.com/epilepsi/pdfs/epilepsi_8_2_113_119.pdf, Erişim tarihi: 29 Nisan 2017

7. Toklu Z. Epilepside Tedavi Stratejileri. Kocatepe Tip Dergisi 2015, Nisan; 16: 147-150.

8. Coşkun A. Prekonsepsiyonel Bakım ve Danışmanlık: Kadın Yaşamındaki Yeri ve Önemi. Hemşirelikte Ĕgitim ve Araştırma Dergisi 2012; 8 (3): 8-15.

9. Başgöl Ş, Oskay Ü. Prekonsepsiyonel Dönemde ve Gebelikte Kanıt Temelli Yaklaşımlar. International Journal of Human Sciences 2012; 9 (2),-1524-1534

10. Madazlı R, Öncül M, Albayrak M, Uludağ S, Eşkazan E, Ocak V. Gebelik ve Epilepsi 44 Olgunun Değerlendirilmesi. Cerrahpaşa Tip Dergisi 2004; cilt(sayl) 35(3).

11. Kutlu G, B. Gömceli Y, Sönmez T, Sanıvar F, E. Inan L. Epileptik Kadınların Gebelik Sirasında Takip ve Tedavisi 2007; 13(2-3): 83-86. 
12. Erten N, Erişgin Z. Gebelikte Epilepsi Tedavisinde Yeni Nesil Antiepileptik İlaçlar. Harran Universitesi Tip Fakültesi Dergisi 2014; 11 (3): 297-303.

13. Baysoy NG, Özkan S. Gebelik Öncesi (Prekonsepsiyonel) Bakım: Halk Sağlığı Perspektifi. Gazi Med.J. 2012; 23: $77-90$

14. Ahmad AEpilepsy: Clinical Considerations In Women Of Childbearing Age. Bangladesh Journal of Medical Science 2013, 4 october; Vol. 12 No, 364-369.

15. Wide K, Winbladh B, Tomson T, Kalen B. Body Dimensions of Infants Exposed to Antiepileptic Drugs In Utero: Observations Spanning 25 Years. Epilepsia.2000; 41(7):854-861.

16. Wilson RD, Davies $G$, Desilets $V$, Reid GJ, et al. The Use of Folic Acid fort he Prevention of Neural Tube Defects and Other Congenital Anomalies. J.Obstet GynaecolCan.2003; 25 (11):959-73.

17. Borgelt LM, Hart FM, Bainbridge JL. Epilepsy During Pregnancy: Focus on Management Strategies. Int J Womens Health, Sep 2016);19 (8): 505-517.

18. Thomas SV. Managing Epilepsy in Pregnancy. Neurol India, 2011; 59 (1): 59-65.

19. Adab N. ,W. Chadwick DReview Management of wo men with epilepsy during pregnancy, The Obstetrician \& Gynaecologist 2006; 8: 20-25.
20. Rauchenzauner M, Ehrensberger M, Prieschl M, Kapelari K, et alGeneralized Tonic-Clonic Seizures and Antiepileptic Drugs During Pregnancy-a Mater of Importance Fort he Baby? J. Neurol.2013; 260 (2):484-488.

21. Borthen I, Eide MG, Daltveit AK, Gilhus NE. Delivery Outcome of Women With Epilepsy: A population-based Cohort Study. BJOG 2010; 117:1537-1543 http:// $d x .147105528 .2010 .02694 . x P M i d: 20716254$, Erişim tarihi: 29 Nisan 2017

22. Veiby G, Daltveit AK, Engelsen BA, Gilhus NE. Pregnancy, delivery and Outcome fort he Child in Maternal Epilepsy. Epilepsia, 2009; 50(9): 2130-2139.

23. Ikonomidoua C, Turski L Antiepileptic Drugs and Brain Development. Epilepsy Research, 2010; 88 (1):1122

24. Bayrak M, Bozdă̆ H, Karadă̆ C, Günay T, Göynümer G. Epilepsi Tanilı Gebelerde Obstetrik ve Perinatal Sonuçların Retrospektif Analizi. IKSST Dergisi 2014; 6(3). 127-132.

25. Bebek N, Baykan B. Epilepsilerin Genetik Yönü ve İyopatik Epilepsi Genetiğinde Son Gelişmeler, Journal of Neurological Sciences 2006; 23 (2): 70-83.

26. Bromley R.L, Baker G.A. Fetal antiepileptic drug exposure and cognitive outcomes. Seizure:Eur J Epilepsy 2016 http://dx.doi.org/10.1016/j.seizure.2016.10.006, Erișim tarihi: 29 Nisan 2017 